\title{
To Kill or not to Kill: The Eradication of Contagious Bovine Pleuro-Pneumonia in Western Europe
}

\author{
JOHN FISHER*
}

The use of slaughter or "stamping-out" programmes has been a consistent feature of public animal health strategies, in Western Europe at least, for some three centuries to the present date. Originally developed in the early eighteenth century, the concept survived the explosion of veterinary scientific knowledge and capacity from the late nineteenth century onwards. Its importance has been maintained to the present day because stamping out works; killing diseased animals and those in close proximity is an effective means of preventing the spread of infections and usually a necessary basis for their eradication in a given region or country. As critically, it has usually proved the most cost-effective answer to infectious livestock diseases, even those characterized by low mortality. ${ }^{1}$

If such programmes are being questioned at the beginning of the twenty-first century, it is because the parameters for evaluating costs and benefits have shifted. Livestock husbandry is no longer a matter of pure material calculation, as was demonstrated during the epizootic of foot-and-mouth disease in Great Britain and the Netherlands in 2001. The general population feels uneasy confronted with the mass slaughter of animals and the holocausts of carcasses, especially when the disease offers little threat to either livestock or human life. Further, the mass slaughter of livestock impinges on economic sectors, notably tourism, that have become more important than farming itself.

Nevertheless, a slaughter programme has never been a matter of blanket application; its use and extent depends on the specific nature of the disease and other circumstances. Further, there are - and have long been-alternatives to mass slaughter. "Vaccination", in the sense of the deliberate and scientific attenuation of disease organisms to prevent infection, may date only from the time of Pasteur. However, as an empirical mode of attenuation, usually termed "inoculation", it was employed well before Jenner developed his vaccine against smallpox. ${ }^{2}$ Effective control strategies involve choices, as is demonstrated below.

The article presents a broad overview, firstly of the evolution of slaughter programmes and their key features as these developed in Western Europe, and secondly of their

\footnotetext{
* John Fisher, PhD, School of Policy, Faculty of Business and Law, University of Newcastle, Callaghan, New South Wales 2308, Australia.

I would like to thank Drs Peter A Koolmees and August H H M Mathijsen, of the World Association for the History of Veterinary Medicine and the Faculty of Veterinary Medicine at the University of Utrecht, for their help with research into the present topic. Without Peter's contribution, in relation to a range of European references, this article could not have been written.
}

\footnotetext{
${ }^{1}$ See, for example, P B M Berentsen, A A Dijkhuizen and A J Oskam, "A critique of published cost-benefit analyses of foot-and-mouth disease', and 'A dynamic model for cost-benefit analyses of foot-and-mouth disease control strategies', Prev. Vet. Med., 1992, 12: 217-27, 229-43.

${ }^{2} \mathrm{C}$ Huygelen, 'The early years of vaccinology: prophylactic immunization in the eighteenth and nineteenth centuries', Sartoniana, 1997, 10: 79-110.
} 


\section{Eradication of Contagious Bovine Pleuro-Pneumonia}

temporary eclipse in the mid-nineteenth century. The main focus, however, is on their later renewal, at a time when germ theory and Pasteurian immunology were transforming attitudes towards the treatment of infectious diseases, whether of humans or livestock. The central theme here is the choice of strategies employed by the various national veterinary services in the eradication of contagious bovine pleuro-pneumonia (CBPP).

The veterinary bureaucracies of the time in Europe, some of which were very recent formations, were conscious of their new capacities, and anxious to demonstrate their professional value. In the case of CBPP they seemingly had a choice of weapons: they could either try to stamp out the disease or employ the pre-Pasteurian form of vaccination known as "tail inoculation" (for its nature, see below, pp. 319-20). The choices made differed quite radically across the major states and the reasons for this are investigated here.

\section{The Origins of Stamping-Out}

The initial stimulus to develop livestock disease control programmes was provided by a series of major incursions of rinderpest into Western Europe from its homeland in the Eurasian steppes from at least the seventeenth century onwards. Rinderpest, or "cattle plague", as its name attests, was regarded as the livestock equivalent of bubonic plague. It was marked by levels of mortality among cattle even higher than for its human synonym, and it seems probable that the use of such countermeasures as isolation and quarantine against rinderpest owed something to public policies against plague. ${ }^{3}$ The crucial further step, the slaughter of diseased stock and the slaughter or isolation of those in contact with them, appears to have evolved quite independently in Italy, Britain and the Austrian Netherlands. ${ }^{4}$

Slaughter and/or quarantine as policies necessarily involved other elements if they were to succeed. Above all else, they required a high degree of compliance from stockowners. This could be achieved only by a mixture of punitive regulation and compensation for slaughtered animals, preferably the full live-weight value of stock to owners who faced the loss of their livelihood. Further, an effective slaughter programme wàs logically complemented by controls over livestock movement, amounting at times to the complete prohibition of internal trade, together with quarantine or prohibition of entry at state borders. A further extension of such strategies was to try and gain information of likely future threats. The sum of these measures explains why action could be undertaken only by the state. Compensation was expensive, while slaughter and trade restriction were unlikely to be popular. Only the state had the resources to support such programmes and the power to deal effectively with offenders.

\footnotetext{
${ }^{3}$ R A Dorwart, 'Cattle disease (Rinderpest): prevention and cure in Brandenburg, 1665-1732,' Agric. Hist., 1959, 35: 79-85; John Broad, 'Cattle plague in eighteenth-century England', Agric. Hist. Rev., 1983, 31: 104-15.

${ }^{4}$ Broad, op. cit., note 3 above, pp. 106-8; J A Faber, 'Cattle plague in the Netherlands during the eighteenth century', Mededelingen van de Landbouwhogeschool
} 


\section{John Fisher}

The slaughter programmes against rinderpest in the eighteenth century were attended by a high degree of success in most cases, a tribute to the growing power and competence of the European states in undertaking what Eric Jones has called "disaster management". 5 Their nature can also be related to the intellectual ethos of the Enlightenment, to a new willingness to search out and experiment with novel remedies for traditional problems. Variations in this ethos also help to explain something of the later development of the programmes.

By the eighteenth century, significant differences had already emerged between, on the one hand, Britain and the Netherlands, and, on the other, the monarchies of the ancien régime. The former states were more commercial in orientation, less centralized and bureaucratic and less prone to interfere in the economy and society. Thus, in Britain, where slaughter programmes had encountered considerable resistance, governments were relatively loath to interfere with private commerce. Their slaughter programmes were dismantled once successful, to be forgotten for a century. ${ }^{6}$

The British Isles also had the advantage of relative isolation from the source of the rinderpest epizootics in the Russian steppes. Conversely, Prussia lay across their path and its rulers developed and maintained the type of strict measures consistent with an authoritarian tradition. Slaughter programmes were complemented by trade interdicts and the use of the army to mount a border cordon in response to information of the approach of rinderpest. Such measures continued into the late nineteenth century, despite the cordon being both outflanked and penetrated in the $1850 \mathrm{~s}$ and $1860 \mathrm{~s}^{7}$

A dirigiste tradition also marked the evolution of livestock disease control in France, where the first use was made of some sort of veterinary expertise. The earliest programmes had been developed by physicians and enforced by police or military services but, in 1763 , the graduates of the newly-founded veterinary school at Lyons were employed to meet an incursion of rinderpest. Their success led to official recognition of veterinary graduates, in France at least, as the appropriate personnel to mount public defences against rinderpest. ${ }^{8}$

The ingredients were thus in place in the late eighteenth century for the construction of a permanent public service against rinderpest and other infectious livestock diseases. The French veterinary schools at Lyons and Alfort were the first of many such foundations in Western European states by the end of the century (significantly, only the British school was privately rather than publicly funded). ${ }^{9}$ There was no further development, however, towards a veterinary bureaucracy. Most states did develop a full apparatus of laws and regulation on procedures to be used against epizootics. Veterinary school graduates did receive financial support from the state in France and Prussia. But in neither did a

\footnotetext{
${ }^{5}$ Eric Jones, The European miracle, Cambridge University Press, 1981, pp. 139-49.

${ }^{6}$ Broad, op. cit., note 3 above, p. 109; John Fisher, 'British physicians, medical science, and the cattle plague, 1865-66', Bull. Hist. Med., winter 1993, 67: 672-90.

${ }^{7} \mathrm{G}$ Steger, 'Frischfleisch und Rinderpest. Probleme frühere Handelswege', Deutsche Tierärztliche Wochenschrift, 1986, 93: 150-4; W Schönherr, 'History of veterinary public health in Europe in the 19th century', Revue scientifique et technique. Office international des épizooties, 1991, 10: 985-94, pp. 989-90; J B Simonds, 'Report on Steppe Murrain or
}

Rinderpest', J. R. Agric. Soc. England, 1857, 18: 197-270, pp. 223-7.

${ }^{8} \mathrm{~J}$ Rameau, 'Le curé de Saint-Lupicin et l'épizootie de 1763,' Rev. Hist. Phar., 1968, 19: 184-6; Robert B Kreiser, " "La Cendrillon des sciences": towards the professionalization of veterinary medicine in eighteenth- and nineteenth-century France', in A Mathijsen (ed.), The origins of veterinary schools in Europe: a comparative view, Utrecht, Veterinair Historisch Genootschap, 1997, pp. 14-15.

9 John Fisher, 'The European Enlightenment, political economy and the origins of the veterinary profession in Britain', Argos, 1995, 12: 45-51. 


\section{Eradication of Contagious Bovine Pleuro-Pneumonia}

centralized system develop to meet the problem of epizootics before the mid-nineteenth century. In France, local veterinarians eked out a precarious existence with little money or authority. ${ }^{10}$ In Prussia, district veterinarians were also poorly paid and not even responsible for the implementation of regulations against rinderpest until well into the nineteenth century. ${ }^{11}$

A variety of reasons can be advanced for this hiatus. The French Wars were one early factor. Wars made for the dissemination of livestock diseases while inhibiting countermeasures. Thereafter, in the first half of the nineteenth century, there was something of an intellectual reaction against theories of disease causation based on contagion or infection, ${ }^{12}$ although, with some exceptions, ${ }^{13}$ this was more muted in veterinary circles than medical. Certainly, measures based on the premise that rinderpest was contagious remained in force on the borders of the most vulnerable states. As noted above, Prussia maintained a military cordon, while the Austrian Empire kept its strict border controls against rinderpest when those against bubonic plague were allowed to fall into disuse. ${ }^{14}$

The Prussian and Austrian cordons may have provided a degree of protection to countries to their west. Certainly, during the forty years after the end of the French Wars the threat of rinderpest receded to the point of being almost forgotten in Britain and the Netherlands. In its absence, the main threat of stock losses came from two other infectious livestock diseases, CBPP and foot-and-mouth disease (FMD). And neither veterinary expertise nor slaughter policies could control or contain these diseases where enzootically established.

Given the extreme infectivity of FMD, its associated low mortality, and a high level of doubt over whether it was actually infectious, it is not surprising that little effort was made to control its incidence. Veterinarians offered cures but these did little beyond bringing the incipient profession into disrepute. ${ }^{15}$ CBPP was the more serious threat; it was attended by death rates second only to rinderpest. However, although most veterinarians considered CBPP contagious, they had no remedy to offer stockowners. One factor was that they knew little about this or any other disease of cattle. Veterinary research and training in the new colleges had their focus overwhelmingly on the horse in the first half of the nineteenth century. ${ }^{16}$ The distinct pathology of CBPP had been described in the eighteenth century, but features of its aetiology remained controversial much later. Even more importantly, as will be seen below, although it was stamped out in some regions, certain characteristics of the disease made it more difficult to deal with than rinderpest.

\footnotetext{
${ }^{10}$ George Fleming, Animal plagues: their history, nature, and prevention, vol. II: Chronological history of animal plagues from A.D. 1800-1844, London, Baillière, Tindall and Cox, 1882, pp. 39-46; Caroline C Hannaway, 'Veterinary medicine and rural health care in pre-revolutionary France', Bull. Hist. Med., 1977, 51: $431-47$.

${ }^{11} \mathrm{~J}$ A W Dollar, 'Notes on the Berlin Veterinary School', Veterinary Record, 1892, 4: 349-50; R Froehner, 'Zur Entwicklung des Veterinärwesens in Preussen', Tierärzl Mitteil, 1929, 10: 439; Schönherr, op. cit., note 7 above, pp. 988-91.

${ }^{12} \mathrm{E}$ Ackerknecht, 'Anticontagionism between 1821 and 1867', Bull. Hist. Med., 1948, 22: 562-93.
}

\footnotetext{
${ }^{13}$ See, for example, William Dick, 'On the noncontagious nature of epizootic diseases', Trans. Highland agric. Soc., 1859, 22: 265-81.

${ }^{14}$ G E Rothenberg, 'The Austrian sanitary cordon and the control of the bubonic plague, 1710-1871', J. Hist. Med. Allied Sci., Jan. 1973, 28: 15-23, p. 22.

$15 \mathrm{~J}$ R Fisher, 'Animal health and the Royal Agricultural Society in its early years', J.R. Agric. Soc. England, 1982, 143: 105-10.

${ }^{16}$ Kreiser, op. cit., note 8 above, pp. 15-16; M F Brumme, 'The emergence of veterinary instruction in the German language area: a preliminary typological study', in Mathijsen (ed.), op. cit., note 8 above, pp. 31-7.
} 


\section{Contagious Bovine Pleuro-Pneumonia}

The origins of CBPP are obscure. References to an origin in Switzerland in the eighteenth century ${ }^{17}$ only reflect its earliest identification there as a separate disease-as distinct from "murrains" in general. ${ }^{18}$ A contagious, febrile disease of cattle and goats, CBPP is a chronic affection caused by Mycoplasma mycoides subspecies mycoides. Like rinderpest, it is normally spread by animal to animal contact but, unlike rinderpest, it has a relatively long incubation period of normally three to six weeks, but can be much shorter or longer. Further, cattle can have the disease and be contagious well before they exhibit overt symptoms, recovered animals remain contagious and, although infection is normally spread through close contact, droplets from the respiratory tract can travel over some distance. ${ }^{19}$ Such characteristics make CBPP difficult to deal with; it made a number of incursions into southern Europe during the 1980 s and 1990 s, and was hard to eradicate. ${ }^{20}$

The characteristics also made for marked regional disparities in incidence. The early dissemination of CBPP has been linked to the French Wars ${ }^{21}$ but its continuing spread was due to the trade that supported the growth in specialisation of cattle enterprises. In the early nineteenth century, and whatever its origin, the disease became associated with the general movement of cattle from east to west, from relatively low price regions practising extensive pastoralism to the relatively high price regions where specialization in cattle rearing and cattle products was greater. Within the west, its incidence was highest where production was most intense, as in dairying and fattening. Town dairies and centres where cattle were fattened on the cheap waste from food processing became especially notorious for CBPP. Alternatively, regions where farmers bred their own stock and sold their produce or cattle out remained largely free of the disease. The differences had major implications for disease control, as can be demonstrated from the experience of the Netherlands, among other regions, in the early nineteenth century.

The early commercialization of the Dutch economy led to specialist dairying by the sixteenth century, although substantial exports only began in the nineteenth. ${ }^{22}$ The Netherlands was also an early international market centre for cattle, and suffered particularly badly from the three waves of rinderpest in the eighteenth century. The scene for

\footnotetext{
${ }^{17}$ DE Salmon, 'Some examples of the development of knowledge concerning animal diseases', Yearbook of the United States Department of Agriculture, 1899, Washington, Government Printer,1900, p. 109;

B H Slicher van Bath, The agrarian history of western Europe 500-1850, transl. O Ordish, London, Edward Arnold, 1963, p. 296.

${ }^{18}$ George Fleming, Animal plagues: their history, nature, and prevention, vol. I: Chronological history of animal plagues from B.C. 1490 to A.D. 1800, London, Chapman and Hall, 1871, p. 198.

${ }^{19} \mathrm{~J}$ R Hudson, 'Contagious bovine pleuropneumonia', FAO Agricultural Studies, No. 86, Rome, 1970. See also E A ter Laak, 'Contagious bovine pleuropneumonia', Vet. Q., 1992, 14: 104-10, and J Blancou, 'Early methods for the surveillance and control for bovine pleuro-pneumonia', Revue
}

scientifique et technique. Office international des épizooties, 1996, 15: 1263-7.

${ }^{20}$ R A J Nicholas et al., 'A comparison of serological tests and gross lung pathology for detecting contagious bovine pleuropneumonia in two groups of Italian cattle', Vet. Rec., July 1996, 139: 89-93; A Linden and D Desmecht, 'La pleuropneumonie contagieuse bovine: historique, agent étiologique, aspects clinique et lésionnel', Vlaams Diergeneeskundig Tijdschrift, 2000, 69: 149-53, p. 150.

${ }^{21}$ Fleming, op. cit., note 18 above, p. 531; D Karasszon, A concise history of veterinary medicine, Budapest, Akadémiai Kiad, 1988, pp. 291-2.

${ }^{22} \mathrm{R}$ T Griffiths, Industrial retardation in the Netherlands, 1830-1850, The Hague, Martinus Nijhoff, 1979, pp. 27-9. 


\section{Eradication of Contagious Bovine Pleuro-Pneumonia}

extensive experiments with inoculation, ${ }^{23}$ this failed to prevent the loss of thousands of animals. Only after a slaughter policy was adopted in a 1799 Act, backed by compensation payments from a Cattle Fund levied on stockowners, was the disease effectively contained, with a further outbreak around Utrecht in 1813 also quickly eradicated. ${ }^{24}$ The Fund yielded sufficient revenue to underwrite the foundation of a veterinary school in Utrecht in 1821, the last of the major European foundations. ${ }^{25}$ However neither its graduates nor the slaughter policy proved of great value against CBPP after its initial incursion from Germany in 1833.

Its introduction was inevitable with the revival of the European cattle trade after the end of the French Wars, with an estimated 40,000 cattle moving annually across its borders by the $1830 \mathrm{~s} .{ }^{26}$ An extensive internal trade led to its rapid dissemination. Although there were few urban dairies in the Netherlands, due to the excellent water transport system, ${ }^{27}$ there was an active trade in store cattle and the unwanted calves that were by-products of intensive milking. CBPP quickly became enzootically established and the Cattle Fund was bankrupted in 1849 by claims for compensation. By mid-century the Netherlands had become "the hot-bed of pleuro-pneumonia", ${ }^{28}$ in the later words of a German veterinarian. It was the source of infection for the British Isles, North America and South Africa. ${ }^{29}$

Incidence of the disease was nevertheless highly variable. It was worst where cattle density and turnover were highest, as in what was known as the "Spoelingdistrict" near Rotterdam in the province of South Holland, a centre for distilling where cattle were fattened in large numbers on the waste. It was also prevalent in the dairy sector, as in Friesland and Groningen, ${ }^{30}$ but there were few cases in breeding and rearing regions. In the province of Zealand, for example, a local veterinarian succeeded in stamping out CBPP in 1839. Strict controls maintained the province's disease-free status afterwards. ${ }^{31}$

The same pattern held throughout Western Europe. CBPP became enzootic in urban dairies and fattening centres. This was notably the case at Magdeburg in Saxony, the major German centre for the sugar beet industry. Besides the cattle fed off the waste products, large numbers were required for haulage. Conversely, the Scandinavian countries, where cattle movements were overwhelmingly outwards, remained free from the disease. In Sweden (then including Norway), the few isolated outbreaks due to imported cattle were quickly

\footnotetext{
${ }^{23} \mathrm{C}$ Huygelen, 'The immunization of cattle against rinderpest in eighteenth-century Europe', Med. Hist., 1997, 41: 182-96.

${ }^{24} \mathrm{C}$ Offringa, Van Gildestein naar Uithof: 150 jaar diergeneeskundig onderwijs in Utrecht, Rijksuniversiteit te Utrecht, 1971, pp. 23, 34.

${ }^{25}$ P A Koolmees and A H H M Mathijsen, 'The development of veterinary medicine in the Netherlands. A chronological orientation since 1700', Argos, 1993, 8: $227-8$.

${ }^{26}$ George Armatage, 'On pleuro-pneumonia', Trans. Highland agric. Soc. Scotland, Feb. 1870, 4th series, 2: 46-81, p. 76.

${ }^{27}$ Charles Whitlaw, On the management of dairies in Holland: on the management of dairies as now conducted in London: to the Right Hon Sir John Sinclair, Bart. \&c. \&c., original edition 1830[?], New Haven, Conn., Goldsmith-Kress Library no.26164, microfilm, 1980.
} 


\section{John Fisher}

stamped out. ${ }^{32}$ Even Denmark remained free, although CBPP was enzootic in the border province of Holstein. Rigorous border controls and the rapid slaughter of any imports that later proved to have the disease maintained its status. ${ }^{33}$ The validity of the stamping out model was thus still apparent, but this was of little value in most of Western Europe. The scale of cattle movements made control impossible, the disease became enzootic and was regarded as an occupational hazard by most stockowners by the $1840 \mathrm{~s}$.

\section{Tail Inoculation}

The costs of CBPP were heavy. Although not all cattle were infected, death rates were high-some 30 per cent of herds, it was estimated, even when the disease had become enzootic. Another 30 per cent suffered a severe depreciation in value (although the meat could safely be eaten). ${ }^{34}$ It was the most serious problem facing European cattle producers in an otherwise favourable market. ${ }^{35}$ There was thus every incentive to develop a "magic bullet" (to anticipate Paul Ehrlich's famous concept), ${ }^{36}$ with inoculation, which had been successful against sheep-pox as well as smallpox, ${ }^{37}$ the favoured possible remedy. Various French and German experiments failed ${ }^{38}$ before a Belgian physician, Louis Willems, developed a successful method. His father had incurred serious losses to CBPP while fattening cattle off distillery wastes at Hasselt, and the son made an intensive study of the disease while experimenting with inoculation in the 1840 s.

Willems' innovation was to transmit the disease agent by an unnatural route that attenuated its impact. In the course of experimentation, he used the serous fluid from the lungs of animals slaughtered after being infected by CBPP, and inoculated the material into the tails of healthy cattle. By 1852 , he was satisfied that this gave immunity to the disease, and he published his results in his Mémoire sur la pleuropneumonia épizootique du bétail. $^{39}$ Given the importance of the topic, his claims naturally received international attention. All the major Western European governments, except that of Britain where the Royal Agricultural Society took this role, ${ }^{40}$ instructed their leading veterinarians to test the Willems' method.

\footnotetext{
${ }^{32}$ E Schoeg, 'Elakartad lungsjuka, dess förekomst $\mathrm{i}$ Sverige på 1840-, 50- och 60-talen', Svensk veterinärtidskrift, 1901, 6: 161-76.

${ }^{33}$ Simonds, op. cit., note 7 above, pp. 214-17; Count C F Danneskiold-Samsoe, evidence to the Select Committee on the Cattle Plague,1877, see note 28 above, Qs. 391-3.

${ }^{34}$ E Semmer, 'Lungenseuche', in Alois Koch (ed.), Encyclopädie der gesammten Thierheilkunde, Vienna, Moritz, 1889, 6: 174-89.

${ }^{35}$ Blancou, op. cit., note 19 above, p. 1280 ; J Gamgee, 'Statistics of loss amongst live stock in the United Kingdom', Edin. Vet. Rev., Aug. 1863, 5: 476-81.

${ }^{36}$ See, for example, Allan Chase, Magic shots: $a$ human and scientific account of the long and continuing struggle to eradicate infectious diseases by vaccination, New York, William Morrow, 1982, p. 159.

${ }^{37} \mathrm{C}$ Huygelen, 'The early years of vaccinology: prophylactic immunization in the eighteenth and
}

nineteenth centuries', Sartoniana, 1997, 10: 79-110.

${ }^{38}$ Angela von den Driesch, Geschichte der Tiermedizin, Munich, Callwey, 1989, p. 184; William Youatt, 'On epizootic diseases', Veterinarian, 1842, 15: 165-9, 241-51, 343-7 and 399-409, p. 347.

${ }^{39}$ Louis Willems, Mémoire sur la pleuropneumonia épizootique du bétail, Bruxelles, Th Lesigne, 1852. This was published simultaneously in Flemish: Verhandeling over de longziekte van het vee, en de middelen om hetzelve er tegen te behoeden, Ghent, Van F en E Gyselynck. For details on Willems, see C Huygelen, 'Louis Willems (1822-1907) and the immunization against contagious bovine pleuropneumonia: an evaluation', Verhandelingen van de Koninklijke Academie voor Geneeskunde van België, 1997, 59: 237-9, 249-52.

${ }^{40}$ At the suggestion of Prince Albert (the nephew of the Belgian king); see Farmers' Magazine, Feb. 1853, 3rd series, 3: 76. 


\section{Eradication of Contagious Bovine Pleuro-Pneumonia}

The results were mixed. The report from Belgium was highly critical, while those from France, the Netherlands and Prussia were cautiously favourable. ${ }^{41}$ The British response, after high initial interest, ${ }^{42}$ proved the most unfavourable. J B Simonds, a professor at the Royal Veterinary College, found Willems overly dogmatic and the two quarrelled over their observations of the outcomes of various trials. Simonds' distaste for Willems' technique was made evident: "surgical and scientific techniques certainly did not rule in these operations", 43 while his later attempts to replicate Willems' technique proved unsuccessful. ${ }^{44}$ As Simonds was virtually the only British authority on cattle diseases, his opposition to tail inoculation had lasting consequences.

The variable outcomes and verdicts reflected the contemporary limitations of scientific method as much as those of Willems' technique. It was generally agreed that some immunity was conferred by tail inoculation but how much (or for how long) was seriously at issue. The degree of success depended on how the test was conducted and how the operation was performed, as well as on the source, the virulence and the age of the "pleural" or "pulmonary exudate" (fluid either from the pleural cavity or encystments in the lungs of a diseased animal) used. There were so many variables that could easily go wrong that the caution of official veterinarians was understandable.

Inoculation also led to many animals losing their tails and to the inadvertent transfer of other diseases. Nevertheless, and although it was not an ideal magic bullet, it became widely adopted, especially in the Netherlands. ${ }^{45}$ Its great advantage for the individual stockowner was its cost-effectiveness. It gave an appreciable extension to the productive life of cows in urban dairies, and a degree of security to fatteners buying store stock. It was also extremely popular with private veterinarians. Although the basic technique was simple enough to be employed by stockmen (as it was extensively in Australia ${ }^{46}$ ), professional veterinarians were the chief inoculators throughout Europe, providing a major boost to their status and incomes. It was even widely employed in English urban dairies, ${ }^{47}$ despite Simonds' disapproval. Further, Willems and continental veterinarians continued to experiment with inoculation, improving its reliability appreciably over the next twenty or thirty years. It was then, from the 1870 s, that it became seriously considered as an option to be used to eradicate CBPP.

\section{Towards Containment and Eradication}

The thirty years to 1860 saw CBPP established on all major land masses apart from South America. After another thirty years, it was in general retreat except perhaps in Africa north

\footnotetext{
${ }^{41}$ Huygelen, op. cit., note 39 above, pp. 261-8.

42 Farmer's Magazine, March 1853, 3: 221-5; Nov. 1853, 4: 415-17.

43 J B Simonds, 'Report on inoculation for pleuropneumonia in cattle', J. R. Agric. Soc. England, 1852, 13: 373-85, p. 379.

${ }^{44}$ Idem, 'Report on the prevention of pleuropneumonia in cattle by inoculation', J. R. Agric. Soc. England, 1853, 14: 244-73.

$45 \mathrm{~J}$ W Buisman, Tussen vroomheid en Verlichting. Een cultuurhistorisch en-sociologischonderzoeknaar enkele aspecten van de Verlichting in Nederland
}

(1755-1810), Zwolle, 1992, pp. 109-55; J de Vries, 'Veeartsen in Friesland 1850-1900', Argos, 1995, 13: 87-93.

${ }^{46}$ John Fisher, 'Pastoral development and the veterinary profession in Australia, 1850-1900', Aust. Vet. J., 1995, 72: 126-31.

${ }^{47}$ Armatage, op. cit., note 26 above, pp. 60-2; evidence of Henry Woodruff in Report of the Departmental Committee appointed to inquire into pleuro-pneumonia and Tuberculosis in the United Kingdom. Part I (BPP, 1888, XXXII [C.5461]), Qs. 4314-416. 


\section{John Fisher}

of the Zambesi and Central Asia. The means that enabled this transformation arose out of a number of developments, notably the growth in knowledge of CBPP aetiology and the continually improving mode of tail inoculation. The impetus towards eradication in Western Europe, however, came from other developments.

The first of these was a resurgence of rinderpest in Western Europe in the 1850s and 1860s. The validity of slaughter policies was again fully demonstrated in its containment and eradication and, unlike in the previous century, the institutional means employed to meet the threat were now maintained and even augmented. Agricultural ministries in each state acquired a new or an increased veterinary capacity. New organizations were founded in the Netherlands and Britain, ${ }^{48}$ and, in each, public veterinarians were given a new level of authority in initiating and implementing disease control strategies. With rinderpest subsiding as a threat in the 1870s (except in Germany), they could turn their attention to other diseases, with control of CBPP naturally a major objective. Beyond the direct losses due to the disease, an added incentive for several countries was the rapid growth of the trade in live cattle, and especially the export of store and fatstock to Britain. ${ }^{49}$

There were still major difficulties to be faced. By the $1860 \mathrm{~s}$, veterinarians had become well aware of CBPP's variable and potentially lengthy incubation period. The first two International Veterinary Congresses, held in Hamburg in 1863 and in Vienna in 1865, saw leading authorities debate the implications for public policy. There was considerable disagreement on the usefulness of restrictions on cattle movement and trade, and on whether slaughter or inoculation provided the most viable approach to control. ${ }^{50}$ This was immediately before Pasteur's work on germ theory and innovations in immunology helped to validate both approaches, so the debate over their rival merits continued to the end of the century without being resolved. In fact, progress towards eradicating CBPP in the various countries took on something of the nature of a contest between stamping out and inoculation.

The contrasting approaches can be related to Michael Worboys' arguments on the intellectual ethos that has dominated official veterinary thinking in Britain from this period onwards. He portrays the leaders in the British Veterinary Department in the late nineteenth century as advancing "a distinctly veterinary construction of epizootic disease ... expressed in what was termed the 'importation theory of disease' ... The theory was directly associated with 'keeping out', or if and when that failed, 'stamping out'." ${ }^{, 51}$ His theme provides a valuable insight into veterinary thinking over time, particularly the attitude of leading British veterinarians towards germ theories, but it is also somewhat misleading in the present context. Most significantly, if British veterinarians were wedded to "killing

\footnotetext{
${ }^{48} \mathrm{C} \mathrm{J}$ Q Kerstens, 'How it evolved', in Veterinary Work in the Netherlands, The Hague, Ministry of Agriculture and Fisheries Veterinary Service, 1971, pp. 12-25; S Hall, 'The stimulus for statutory control of animal diseases in Great Britain in the nineteenth century', Vet. Rec., 1975-76, N.S., 6: 3-12.

${ }^{49} \mathrm{R}$ Perren, The meat trade in Britain 1840-1914, London, Routledge \& Kegan Paul, 1978, pp. 111-12.

50 John Gamgee, 'Official report of the International Veterinary Congress, Hamburg 14-18 July 1863', and 'Official report of the Second
}

International Veterinary Congress', Vienna 18 July 1865 , in idem, The cattle plague, London, R Hardwicke, 1866, pp. 488-99, 781-7.

${ }^{51}$ Michael Worboys, " "Killing and curing": veterinarians, medicine and germs in Britain, 1860 1900', Vet. Hist., 1992, 7: 53-71, p. 57; see also his 'Germ theories of disease and British veterinary medicine, 1860-1890', Med. Hist., 1991, 35: 308-27; and Spreading germs: diseases, theories, and medical practice in Britain, 1865-1900, Cambridge University Press, 2000, ch. 2. 


\section{Eradication of Contagious Bovine Pleuro-Pneumonia}

not curing" on the grounds of cost-effectiveness, then their approach was firmly in the European mainstream.

In fact, there were a number of ironies to the policy choices made and the objectives attained in different countries. The eradication of CBPP was first achieved in the Netherlands, then in Britain, the original sources of global dissemination. The chief weapon employed in both countries was stamping out, backed by rigorous quarantine, in a dramatic reversal of their previous reluctance to interfere with freedom of commerce. Conversely, in the more dirigiste states of France and Prussia, where CBPP remained enzootic at the end of the century, traditional approaches based on stamping out and quarantine were modified substantially in attempting to contain the disease. As will be seen below, the contrasts provide a nice example of the primacy of economic considerations over cultural tradition.

This was because circumstances differed radically between countries. Thus, Britain, as an island, was in the enviable position of being able to prevent CBPP incursions at a much lower cost than any other country. Second, policy was never the result of coherent, thoughtout planning put into practice. Rather, it evolved over time in response to forces such as the relative political power of various interested groups, which could be at odds with each other. Policy formulation was also marked by considerable interdependence, in part reflecting the nature of the European cattle trade and the manner in which policy in one country had implications for another. Finally, policy makers learnt from experience, either their own or that of others. These themes are explored below.

\section{Britain}

Several hundred thousand live cattle were imported annually into Britain in the course of the $1860 \mathrm{~s}$. In 1865 , this resulted in the introduction of rinderpest and the subsequent epizootic, the "cattle plague", transformed attitudes towards infectious livestock diseases. In particular, it led farmers to establish the Central and Associated Chambers of Agriculture in 1866, in large part to lobby for government measures against disease. ${ }^{52}$ The Chambers movement increasingly sought the prohibition of livestock imports; the threat of disease was the prime overt concern, but breeders, especially, could see the advantages of such restrictions. Over the next three decades, despite the prevailing intellectual orthodoxy on free trade, farmers won a series of measures restricting live imports, a major success being the Contagious Diseases (Animals) Act of $1878 .{ }^{53}$ One provision of the Act was that live cattle had to be slaughtered at the port of entry if they came from any country where CBPP was known to exist. This then included all of Europe north of the Pyrenees and, from 1883, the United States.

It might have been expected that the Veterinary Department of the Privy Council, also founded in response to the cattle plague, would have enthusiastically espoused measures that gave it greater power and relevance at a relatively low cost. However, this was not so at first. J B Simonds, although converted to germ theory by the 1870 s, was sceptical of the thesis that the necessary precondition for CBPP control was to restrict its importation.

\footnotetext{
52 A H H Matthews, Fifty years of agricultural politics: being the history of the Central Chamber of Agriculture, 1865-1915, London, P S King, 1915, pp. $392-4$.
}

\footnotetext{
${ }^{53}$ John Fisher, 'The economic effects of cattle disease in Britain and its containment, 1850-1900', Agric. Hist., 1980, 54: 278-94, pp. $285-6$.
} 


\section{John Fisher}

He also exaggerated the infectiousness of CBPP, arguing that controls on imports were pointless as the disease was so firmly entrenched in Britain that only the most stringent internal measures could reduce its incidence. ${ }^{54}$ As the first state Veterinary Adviser, as editor of the Veterinarian for three decades to 1881, and as Principal of the Royal Veterinary College in the $1870 \mathrm{~s},{ }^{55}$ Simonds had considerable influence. His views were also much to the taste of Liberal free traders who viewed state interference with imports with great suspicion.

Simonds' protégé and successor in the Department, G T Brown, echoed his views in the 1870s. Nevertheless, his term in office saw the prohibition on live imports policed with increasing effectiveness. A shrewd political bureaucrat, Brown moved towards an alliance with the Chambers over time, especially as the political opposition to import controls subsided with the growth of the chilled and frozen meat trade. ${ }^{56}$ Rather than portraying the prohibition of live imports as an alternative to stringent domestic measures, Brown offered them as complements in a programme that could eradicate CBPP.

The 1878 Act had provided for the slaughter of cattle diseased with CBPP, but left implementation in the hands of local authorities. They also bore the cost, and were the more reluctant to enforce slaughter where the incidence of CBPP was high and the cost thus greatest. ${ }^{57}$ Brown sought central government funding and greater departmental powers in the implementation of controls. With the growth of the railway system allowing increased supplies of country milk into the towns, an attraction for the Chambers, representing rural stockowners, was that the chief burden of internal measures would fall on their competitors, the urban dairies that were notorious centres of infection.

The alliance stood Brown in good stead when he faced a further challenge to his programme in the 1880s. Inoculation first surfaced as a serious issue in Britain or, more specifically, in Scotland, during that decade, largely due to the efforts of a peripatetic veterinary surgeon, Richard Rutherford. After a career that saw him practise (and trade in livestock) variously in the United States, India and Australia, ${ }^{58}$ Rutherford returned to Scotland to introduce what he claimed to be a new and improved mode of tail inoculation learnt in Australia. ${ }^{59}$ His method, which essentially meant drawing a seton, contaminated with serous fluid, through the tail, was new to Britain, if not the rest of Europe (it was essentially what Willems described as "le méthode hollandaise", in a tribute to Dutch innovation ${ }^{60}$ ). Nevertheless, Rutherford soon won support from leading Scottish veterinarians, dairymen and cattle fatteners. His supporters were able to exert sufficient political

\footnotetext{
${ }^{54}$ Idem, 'Professor Gamgee and the farmers', Vet. Hist., 1979-80, N.S., 1: 47-63, 57-60; and an editorial in the Veterinarian, Sept. 1876, 4th series, 23: 620-6.

${ }^{55}$ See Iain Pattison, A great British veterinarian forgotten: James Beart Simonds 1810-1904, London, J A Allen, 1990; Ministry of Agriculture, Fisheries and Food (MAFF), Animal health: a centenary, 1865-1965, London, HMSO, 1965, pp. 35, 43.

${ }^{56}$ Fisher, op. cit., note 53 above, pp. 285-6; Perren, op. cit., note 49 above, pp. 123-32.

${ }^{57}$ See, for example, W McCall, 'The suppression of contagious pleuro-pneumonia: inoculation and stamping-out', Veterinarian, Feb. 1887, 60: 201-10, and Report of the Departmental Committee
}

appointed to inquire into pleuro-pneumonia, 1888 , op. cit., note 47 above, Qs. 6476-8, 6603-7 and $8461-4$.

${ }^{58} \mathrm{~J}$ R Fisher, 'Foot and mouth disease in Australia', Aust. Veter. J., May 1984, 61: 158-61, p. 160; J F Smithcors, The American veterinary profession, Ames, Iowa State University Press, 1963, p. 195.

${ }^{59} \mathrm{R}$ Rutherford, 'Inoculation as a prevention of pleuro-pneumonia', Trans. Highland Agric. Soc. Scotland, 1882, 4th series, 14: 14-31.

${ }^{60}$ Louis Willems, Cinquante années d' inoculation préventive de la péripneumonie contagieuse des bovides (1850-1900), Hayez, Imprimeur de l'Académie Royal de Belgique, Bruxelles, 1900, p. 45. 


\section{Eradication of Contagious Bovine Pleuro-Pneumonia}

pressure to win a Departmental Committee on the question, at which Rutherford was given an extensive hearing.

This was not to his advantage. Although, as Worboys notes, inoculation could have been presented as a "scientific" alternative to slaughter, ${ }^{61}$ Rutherford was not interested in this and was happily ignorant of any immunological principles involved. His emphasis was solely on the relative cost-effectiveness of inoculation as a potential basis for eradicating CBPP. Brown, who had inherited his mentor's antipathy to inoculation, ${ }^{62}$ turned this to his own advantage. Other witnesses dwelled on the shortcomings of inoculation, notably that it did not "take" on animals that already had the disease, masking the survival of CBPP and thus exacerbating the critical problem of symptomless carriers. As was also emphasized, the efficacy of inoculation remained variable and there was still uncertainty as to the length of protection given. Under intensive questioning, Rutherford was reduced to unsupported assertions of the complete efficacy and reliability of his method and of his own ability to recognize animals already incubating CBPP. ${ }^{63}$ The Committee's report could hardly do otherwise than come down wholeheartedly in favour of stamping-out. ${ }^{64}$

Brown thus won the debate, eventually gaining the financial support and powers necessary for a rigorous slaughter programme in 1890. The eradication of CBPP was finally achieved in 1898, taking rather longer than promised. One reason for this was continuing problems in gaining compliance from owners and traders, despite compensation payments that were generous in comparison to the plague years of the $1860 \mathrm{~s}^{65}$ The end of the campaign was also thirteen years later than the final success of the Dutch eradication programme, frequently adverted to by the British Veterinary Department as a model of what a slaughter programme could achieve.

\section{The Netherlands}

The British Veterinary Department's close interest in the Dutch campaign of eradication included a special survey in its annual report in $1885,{ }^{66}$ when it was evident the Dutch were close to success. Here, and in evidence to the 1888 Committee, the emphasis was on the critical importance of slaughter. That tail inoculation was also employed was mentioned, only to be dismissed, using selective statistics (the Department's table in its report did not show the numbers of cattle inoculated) as a retrograde step. Further, leading questions to the only Dutch witness to the 1888 Committee, J F Laméris, one of the nine district veterinarians of the Netherlands, responsible for the Province of South Holland including the Spoelingdistrict, led him to assert the critical importance of slaughter over inoculation in the successful programme.

\footnotetext{
${ }^{61}$ Worboys, “ "Killing and curing”', see note 51 above, p. 60; Rutherford's evidence in Report of the Departmental Committee appointed to inquire into pleuro-pneumonia, 1888, see note 47 above, Qs. 918, 928-32, 1070-2.

${ }^{62}$ See Brown's comments in response to a paper on 'Inoculation as a preventive against pleuropneumonia, \&c.', in the Veterinarian, 1887, 60: 682-3.

${ }^{63}$ Rutherford's evidence in Report of the Departmental Committee appointed to inquire into
}

pleuro-pneumonia, 1888, see note 47 above, Qs 976-80, 1114-24.

${ }^{64}$ Report of the Departmental Committee appointed to inquire into pleuro-pneumonia, 1888, see note 47 above, pp. xi-xv.

${ }^{65}$ MAFF, op. cit., note 55 above, pp. $56-63$, $158-62$.

${ }^{66}$ Annual report of the Veterinary Department of the Privy Council Office for 1885, London, HMSO, 1886, pp. 41-4. 


\section{John Fisher}

The picture conveyed was misleading. Slaughter was a necessary component of the Dutch programme but it was complemented by the use of inoculation through the most important phases of the campaign. This was not due to a consciously thought-out strategy. Rather, policy shifted and changed over time according to the balance of contending interests and other circumstances.

The Netherlands had suffered as badly as Britain from the rinderpest epizootic of 1865 and 1866, until it too resorted to stamping out. Thereafter, a permanent state Veterinary Service was established under the Cattle Act of 1870 , albeit with only five district veterinarians who answered to regional authorities as much as to the state Service. ${ }^{67} \mathrm{CBPP}$ was the obvious early priority; quite apart from its local incidence, most of the live cattle trade to Britain from northern Europe passed through Dutch ports like Rotterdam and Flushing, and was under threat from the growth of British restrictions against imported disease.

The first response of the new Service was to issue an Order requiring the slaughter of all herds containing cattle diseased with CBPP. This proved unenforceable, quite apart from the expense of an adequate level of compensation (although the expense was reduced by some 25 per cent by selling the meat and skins from slaughtered carcasses). In response to the protests of stockowners and traders, and after considerable political debate, an official inquiry was instituted, leading to an Act passed in 1874 that required the slaughter of diseased stock and the inoculation of contacts. Professional veterinarians, paid one guilder per inoculation, were made responsible for their own districts. ${ }^{68}$

The modified campaign was a success. Less than 1 per cent of inoculated stock subsequently took the disease, compliance was high and costs greatly reduced. As the incidence of CBPP declined markedly, it allowed various provinces to contemplate complete eradication. The first to act was Friesland where compulsory inoculation for contacts was replaced by compulsory herd slaughter in 1877 . Success led to other provinces following suit to the point where the state Service attempted to reinstitute compulsory herd slaughter nationally in $1878 .{ }^{69}$ Again, this proved premature in the face of poor compliance as, for budgetary reasons, compensation was set at only half an animal's carcass value. Nevertheless, by this time, the core of the continuing problem was easily identifiable as lying in the Spoelingdistrict near Rotterdam with its traditionally high turnover of cattle. Inoculation was reintroduced here and, by 1884 , had sufficiently reduced the numbers of diseased cattle to the point where slaughter could be applied to achieve complete eradication. ${ }^{70}$

It was an irony of the Dutch success, considerable as this was, that a further contributory factor lay in the progressive removal of one of the incentives to undertake an eradication programme. The live cattle export trade to Britain declined rapidly in the late 1870 s, due less to British restrictions than to rising demand and thus meat prices in Germany and France, according to Richard Perren. ${ }^{71}$ This reduced greatly the potential for infection from cattle in

${ }^{67}$ Offringa, op. cit., note 24 above, pp. 169-70.

${ }^{68}$ Verslag aan den Koning van de bevindingen en handelingen van het Veeartsenijkundig

Staatstoezicht, The Hague, Van Weelden en Mingelen, 1874 , pp. $24-7$.

${ }^{69}$ Offringa, op. cit., note 24 above, pp. 170; Verslag aan den Koning, 1879, op. cit., note 68 above, p. 54; $\mathrm{J} \mathrm{J}$ Wester, Geschiedenis der veeartsenijkunde, Utrecht, Hoonte, 1939, pp. 335-40.

\footnotetext{
${ }^{70} \mathrm{M}$ Bettel, 'The eradication of pleuro-pneumonia from Holland', J. Comp. Pathol. Therap., 1889, 2: 3158; Verslag aan den Koning, op. cit, 1884, note 68 above, p. 24; evidence of John May to the Select Committee on the Cattle Plague, 1877, note 28 above, Qs. 1874-2124; evidence of J F Laméris in Report of the Departmental Committee appointed to inquire into pleuro-pneumonia, 1888, see note 47 above, Qs. 7061-212.

${ }^{71}$ Perren, op. cit., note 49 above, p. 121.
} 


\section{Eradication of Contagious Bovine Pleuro-Pneumonia}

transit across the Netherlands, and permitted the adoption of trade bans similar to the British. The last two or three cases of CBPP were in stock introduced from Belgium, with very few cattle exported or re-exported to Britain by the mid-1880s. The point also serves to emphasize the great advantage the British had in seeking to stamp out CBPP.

As the only major importer of livestock, Britain was in a position unilaterally to insist on the terms under which they were given entry. As an island, it was able to police such entry in a more cost-effective fashion than any other European country. The Swiss experience also serves to demonstrate the point. As early as the 1850 s, the Swiss had put in place a stamping out programme that was effective and relatively cheap. Compensation was low but cattle owners were allowed to sell the hides and even the meat of slaughtered stock, these not being considered infectious or a danger to human health. ${ }^{72}$ However, each time that Switzerland was close to claiming completely CBPP free status, introduced stock caused further epizootics that then had to be dealt with. ${ }^{73}$ Full eradication was claimed only in $1895,{ }^{74}$ by which time its major neighbours had achieved this status or were close to it. Countries with even more permeable borders thus faced greater problems and costs in seeking to eradicate the disease.

\section{France}

It was seemingly inevitable that the French would adopt tail inoculation as the core of their control strategies against CBPP. Ronald Hubscher has argued that Pasteurian innovation was a key factor in raising the social and professional status of French veterinarians, ${ }^{75}$ but Willems' innovation played a preparatory if subordinate role. Quite apart from its widespread adoption by veterinary practitioners, Willems' innovation fitted perfectly into the French veterinary research programme that became subsumed under the name of Pasteur. By the mid-nineteenth century, training at the veterinary colleges of Lyons and Alfort had been transformed and staff members such as J-B Auguste Chaveau and Henri Bouley accepted as serious scientists. The research they pursued on "vaccinia" in inoculation underpinned and made possible Pasteur's triumphs with vaccination. ${ }^{76}$ Not surprisingly, they were keenly interested in Willems' innovation. Bouley was appointed to test the technique in 1854, reporting that 96 per cent of inoculated cattle gained immunity. He and Chauveau led in promoting the use of tail inoculation in France and were instrumental in the award of le prix Barbier to Willems in 1882 from the Académie de Médecine of Paris. ${ }^{77}$

Pasteur himself was well aware of and admired Willems' innovation. He originally chose CBPP as the prime focus for his research on vaccination, and only his failure to isolate the causative agent led him to turn from CBPP to anthrax. He encouraged his nephew, Adrien Loir, to experiment with improving the technique of tail inoculation when the latter was in

\footnotetext{
${ }^{72}$ Alois Tschopp, 'Die Tierseuchenbekämpfung in den Kantonen Luzern, Schwyg and Zug von 1798 bis 1900', thesis, Zürich University, 1985, pp. 63-5; Gamgee, op. cit., note 50 above, pp. $492-4$.

${ }^{73}$ Veterinarian, 1876, 49: 158, 225 and 476; Annual report of the Veterinary Department of the Privy Council Office for 1878, London, HMSO, 1879, pp. 48-9.

${ }^{74}$ Tschopp, op. cit., note 72 above, p. 95.
}

\footnotetext{
${ }^{75} \mathrm{R}$ Hubscher, Les Maîtres des bêtes: les vétérinaires dans la société française (XVIIIe-XXe siècle), Paris, Editions Odile Jacob, 1999, pp. 85-7.

${ }_{76}$ Wilkinson, op. cit., note 4 above, pp. 147-61; Hubscher, op. cit., note 75 above, pp. 182-6.

${ }^{77}$ Huygelen, op. cit., note 39 above, pp. 266, 26971 ; Willems, op. cit., note 60 above, pp. $17,38-40,47-$ 8. Hubscher, op. cit., note 75 above, pp. 92-5; see also L-G Neumann, Biographies vétérinaires, Paris, Asselin et Houzeau, 1896, pp. 34-6.
} 


\section{John Fisher}

Australia on behalf of the Pasteur Institute. ${ }^{78}$ Willems reciprocated with keen support for Pasteurian theory and innovation. Like Pasteur, Willems conducted a trial of his technique at Pouilly-le-Fort (under the supervision of Pasteur, Bouley and Chauveau); like Pasteur, he was triumphantly vindicated (and, like Pasteur, possibly lucky to achieve 100 per cent success $^{79}$ ).

At the same time, leading veterinarians remained convinced of the merits of slaughter; it was Bouley and Chauveau who had organized the successful programme that contained rinderpest with minimal losses (apart from the animals in the Paris Zoo) in the 1860 s. So too did Pasteur, who even queried the relevance of his rabies vaccine to the British, when they had the means to stamp out the disease as a prelude to its exclusion. ${ }^{80}$ In the $1870 \mathrm{~s}$, British restrictions led to an abrupt decline in cattle exports to Britain and first led the Agricultural Ministry to contemplate concerted action against CBPP. It was made clear from the outset that while slaughter was the most attractive option, given the scale of the problem, especially in the Paris dairies, cost was the critical factor that militated against its employment. ${ }^{81}$ Inoculation was relatively cheap and acceptable to stockowners although, at first, whether or not it was made compulsory was left to the discretion of local authorities. ${ }^{82}$

As late as 1883 , when it was evident that this strategy was having little impact, there was still a reluctance to go further. Bouley, despite favouring compulsory inoculation, still accepted the need for some local discretion, "in order that the measures should not appear vexatious, but, above all, that they should not expose the public Treasury to grave and heavy charges." ${ }^{83}$ Later in the decade, two adaptations were made. First, Pasteur was given the role of developing a more reliable mode of inoculation, which he did by adopting the technique developed by Loir at his suggestion. This consisted of conducting successive passages of the "virus" (as it was now termed) through calves, and was designed less to attenuate its virulence than to reduce the risk of contamination (not entirely successfully). Second, and more importantly, inoculation was now complemented by slaughter, following the Dutch model, where CBPP incidence had been reduced to manageable proportions.

By the end of the century, it was evident that success was close at hand, the final cases occurring in $1905 .^{84}$ Belgium and Italy had already achieved eradication, employing

${ }^{78} \mathrm{R}$ J Dubos, Louis Pasteur: free lance of science, New York, Charles Scribner, 1960, pp. 324-7; A Loir, 'Reports by M. Loir on experiments made with a view to discovering a mode of preserving the virus of pleuro-pneumonia', Appendix A to P R Gordon, 'Report of the Chief Inspector of Stock and Brands', pp. 3-5, in Votes and Proceedings of the Queensland Legislative Assembly, 1891, vol. 3.

${ }^{79} \mathrm{~J}$ W Ezzell, P Mikesell, B E Ivins and S H Leppla, 'The genetic basis of Pasteur's attenuation of Bacillus anthracis cultures', in H Koprowski and S A Plotkin (eds), The world's debt to Pasteur, New York, Alan R Liss, 1985, pp. 109-16; Gerald L Geison, The private science of Louis Pasteur, Princeton University Press, 1995, ch. 6; Willems, op. cit., note 60 above, pp. 72-4.

${ }^{80}$ Lise Wilkinson, 'The development of the virus concept as reflected in the corpora of studies on individual pathogens. 4: Rabies-two millennia of ideas and conjecture on the aetiology of a virus disease', Med. Hist., 1977, 21: 15-31, p. 30.

\footnotetext{
${ }^{81}$ Vet. J., 1876, 3: 45-6; Annual report of the Veterinary Department of the Privy Council Office for 1878 , London, printed for HMSO by Eyre and Spottiswoode, 1879, p. 36.

${ }^{82}$ For an account of the French campaign, see Emmanuel Leclainche, Histoire de la médecine vétérinaire, Toulouse, Office du Livre, 1936, vol. 2, pp. 118-37.

${ }^{83} \mathrm{M}$ Peuch [professor at the Toulouse Veterinary College], 'Preventive inoculation for contagious pleuro-pneumonia', Vet. J., April 1888, 26: 233-41, p. 240.

${ }^{84}$ Annual report of the Agricultural Department of the Privy Council Office for 1888, London, printed for HMSO by Eyre and Spottiswoode, 1889, pp. 161-7; Willems, op. cit., note 60 above, pp. 67-72; F Hutyra and M Marek, Special pathology and therapeutics of the diseases of domestic animals, Chicago, Alexander Eger, 1914, pp. 390, 404-5.
} 


\section{Eradication of Contagious Bovine Pleuro-Pneumonia}

variations on the combination of inoculation and slaughter that had become the accepted model. This left only one major western European country still facing serious problems in achieving eradication.

\section{Germany}

France had two advantages in controlling CBPP by the time a serious programme was established. First, as elsewhere, the decline of urban dairies under competition from country milk reduced a notorious centre of infection. Secondly, its frontiers were with states where CBPP was either not present or fast being brought under control. Spain had always been free (although the disease was introduced at the end of the century). Belgium, Switzerland and Italy were free or nearly so by the mid-1890s. As for Germany, although CBPP remained a problem well into the next century, the western regions saw only minor sporadic incursions even in the late 1880s. It was in the eastern regions of Germany that CBPP remained enzootic, and this was in part a result of the continuing problem of incursions from further east.

The Prussian authorities had long been accustomed to having to meet periodic invasions of rinderpest from the East, and this also became true of CBPP. Before the formation of the German empire, policies towards CBPP varied among the states, and this remained the case after 1871 , although rinderpest became an imperial responsibility. ${ }^{85}$ It remained a problem as late as the 1880 s, the prime concern above all others. From the early 1870 s, the old military cordon was gradually modified and greater emphasis placed on veterinary expertise and trade interdicts (with a view to reducing the price premium that made cattle smuggling so attractive). However, the states retained separate veterinary departments and policy towards CBPP continued to vary widely.

CBPP had been enzootic in Schleswig and Holstein when these provinces were under Danish rule (and despite Denmark's disease-free status). As part of the German empire, the importance of dairying and cattle exports led them, despite the cost, to institute a herd slaughter programme. This was successful and stringent border controls thereafter kept these provinces largely free of CBPP. ${ }^{86}$ Elsewhere, however, such measures could hardly be contemplated in the face of the potential costs. In Prussia, after 1875, diseased animals were supposed to be slaughtered, but compensation (met by a tax on farmers) and thus compliance were often poor. The emphasis, internally and on the borders, was on a three-month quarantine for introduced or contact stock and, quite apart from compliance problems, this could be inadequate in the face of symptomless carriers. ${ }^{87} \mathrm{Karl}$ Müller, professor at the Berlin Veterinary College, praised the British slaughter programme in 1888, and lamented that "we should have gone the same way in Prussia if we could pay the enormous costs such a stamping-out system would require". 88

Even so, CBPP declined in incidence in Prussia over the next decade, in part due to a decline in urban dairies and more effective border controls with the Russian and Austrian empires. The great exception was the traditional trouble spot of Magdeburg in Saxony (but

\footnotetext{
${ }^{85}$ Von den Driesch, op. cit, note 38 above, p. 184.

${ }^{86}$ Müller's evidence to the Select Committee on the Cattle Plague, 1877, see note 28 above, Qs. 1421-5.
}

\footnotetext{
${ }^{87}$ Ibid., Qs. 1341-8, 1433-8, 1492-8, 1511-16.

${ }^{88}$ Report of the Departmental Committee appointed to inquire into pleuro-pneumonia, 1888, see note 47 above, p. 294, Appendix 7.
} 
part of Prussia after 1866). Müller and his colleague, Andreas Christian Gerlach, at the Berlin Veterinary College, contemplated more stringent controls but faced determined opposition from regional producers and politicians who had long favoured inoculation. ${ }^{89}$ The debate over slaughter or inoculation flared again, and again cost proved the deciding consideration. In 1888, the Magdeburg pastoral association, alarmed by the prospect of a full slaughter programme, induced the Prussian Minister of Agriculture to establish an official trial of inoculation. This was carried out by the noted veterinary pathologist, Wilhelm Schutz, who had a reputation for sensitivity to political considerations. ${ }^{90} \mathrm{He}$ pronounced inoculation an emphatic success, ${ }^{91}$ and it became official policy in Saxony to the end of the century and beyond.

This was presumably a factor in the failure of Germany to eradicate CBPP before the First World War. However, as always, its eastern regions faced much greater problems than other parts of Western Europe. CBPP remained enzootic in the Polish part of the Russian Empire $^{92}$ and, given the continuing price differentials between east and west, Germany was always vulnerable to repeated re-introductions. Further, sugar beet production, unlike urban dairying, was a growth industry, a major contributor to the German economy. In these circumstances, inoculation was a cost-effective alternative to a full eradication programme based on slaughter.

\section{Conclusion}

In 1898, Edmond Nocard and Pierre Roux identified the causal organism of CBPP. ${ }^{93}$ In the same year, in his veterinary textbook, Nocard also stated that "the question of treating pleuropneumonia is of limited value, since the animal disease laws of every country stipulate the slaughter of sick cattle". 94 It was a statement with which veterinarians in state services could all agree; the British Veterinary Department was far from alone in its predilection for slaughter.

The eradication of CBPP in most countries of Western Europe in the late nineteenth or early twentieth centuries was a considerable achievement. While slaughter had worked admirably against rinderpest, and was the preferred centrepiece of strategies against infectious diseases, a combination of different aetiological characteristics and economic considerations made it less appropriate in the case of CBPP. The alternative to slaughter was tail inoculation as developed by Louis Willems, an innovation which derived from a long tradition of empirical experimentation. It anticipated the work of Pasteur, under which "scientific research could pay off so handsomely in practical results", 95 but its popularity

\footnotetext{
${ }^{89}$ Rudolf Disselhorst, Die Tierseuchen, soweit sie unter das deutsche Reichsviehseuchengesetz von 18. Mai 1909 fallen: in 21 Vorlesungen, Berlin, P Parey, 1909, pp. 87-8; Gamgee, 'Official report, 1863', note 50 above, pp. 491-2.

${ }^{90} \mathrm{~L}$ Z Saunders, A biographical history of veterinary pathology, Laurence, Kansas, Allen Press, 1996, pp. $203-4$.

${ }^{91}$ W Schutz, 'Pleuro-pneumonia and its prevention by inoculation', transl. P A Kob, in Votes and Proceedings of the Legislative Assembly, Brisbane,
}

\footnotetext{
Queensland, Government Printer, 1895, vol. 1, pp. 1-23.

92 J Janiszewski, ‘40-ta rocznica stlumienia zarazy plucnej bydla w Polsce', Medycyna Weterynaryjna, 1975, 31: 307-8.

${ }^{93} \mathrm{E}$ Nocard and P P E Roux, 'Le microbe de la péripneumonie', Annales de l'Institut Pasteur, 1898, 12: $240-62$.

${ }^{94}$ Cited in Blancou, op. cit., note 19 above, p. 1280.

${ }^{95}$ Dubos, op. cit., note 78 above, p. 10.
} 


\section{Eradication of Contagious Bovine Pleuro-Pneumonia}

with stockowners was due to its cost-effectiveness. It minimized both the direct costs of a control programme and the indirect costs from disruption to trade and commercial operations generally.

Stockowners proved a powerful force in modifying the preference of state veterinarians for a slaughter programme. In Britain, they achieved their prime objective of import controls before a slaughter programme was seriously mounted. By the time this happened, the costs of slaughter for the main group of stockowners, in rural areas, were relatively low and they were generally willing to give their support. Outside Britain, stockowners proved effective in lobbying their political representatives in favour of tail inoculation, and this was attractive to the latter for the same reasons-its relative cheapness in comparison to slaughter. The resulting policy mix proved efficient as well as cost-effective, especially and earliest in the Netherlands, not least because it made for better compliance. In fact, if there is a lesson from the Western European achievement it would be that, while slaughtering sick and contact animals makes sense against infectious diseases, such a strategy should be adapted to circumstances and implemented with an eye to the size of the costs involved and on who bears these costs. 